\title{
Extent of Community Participation in the Ecotourism Project in Caramoan, Camarines Sur, Philippines
}

\author{
Jocelyn P. Amata \\ San Jose Campus, Partido State University, Del Carmen, San Jose, Camarines Sur, Philippines \\ Email: jocelyn.amata@parsu.edu.ph
}

How to cite this paper: Amata, J.P. (2021) Extent of Community Participation in the Ecotourism Project in Caramoan, Camarines Sur, Philippines. Open Access Library Journal, 8: e7790.

https://doi.org/10.4236/oalib.1107790

Received: July 26, 2021

Accepted: November 15, 2021

Published: November 18, 2021

Copyright $\odot 2021$ by author(s) and Open Access Library Inc.

This work is licensed under the Creative Commons Attribution International License (CC BY 4.0).

http://creativecommons.org/licenses/by/4.0/

\begin{abstract}
Among the municipalities in Camarines Sur, Caramoan presents great economic potential. Along with the town's popularity and perceived ecotourism sustainability, it is important that the dynamics of community participation in the ecotourism projects is understood in order to analyze its significance in sustaining or maintaining the ecotourism projects. This study determined the extent of community participation in the ecotourism project in Caramoan, Camarines Sur. Data were gathered using quantitative method. Self-administered questionnaires were distributed to a total of 97 household heads in Barangay Paniman. Chi-square test of independence, which used 0.5 level of significance, was employed in testing the relationship between the household heads' socio-demographic characteristics, level of awareness, nature of participation, and level of participation. Findings revealed that the nature of participation of the household heads can be described as mere followers of the leaders and supervisors of the project. They involved themselves in the project because they believed that they could be of help to the project and they could benefit from it. The extent of community participation of Barangay Paniman falls under the third level of participation which is participated by consultation. Based on this, it can be said that the level of community participation in the area is low. Of the variables tested for possible relationship with each other, the respondents' socio-demographic characteristics were found to be significantly related to their nature of participation. In addition, the respondents' level of participation was found to be significantly related only to their membership in organizations.
\end{abstract}

\section{Subject Areas}

Sociology 


\section{Keywords}

Ecotourism, Community Participation, Level of Awareness, Socio

Demographic Characteristics, Local Residents

\section{Introduction}

In 2010, the Department of Tourism (DOT) named Caramoan as one of Philippines' top tourism sites. It was also considered as one of the top 14 tourism destinations in the world by Top Resa Travel Fair 2008, an annual key travel trade in France. The place' gaining tourism popularity in recent years is mainly due to advertising, as the place which is endowed with fine white sand beaches beside majestic limestone rock formations was featured many times in news and local television programs. Aside from this, Caramoan also played host for an international TV franchise which brought in many foreign and local tourists in the area. Popular activities that tourists can enjoy in the place include diving, swimming, snorkeling, spelunking, boat riding, island hopping, and site seeing.

According to Moica et al. (2019) [1], tourism in Caramoan has become a major source of income and employment in the community. However, due to the high demand of this industry, the environment is put at risk of degradation and neglect. Results of their study revealed that the community and tourists consider proper waste management an important factor but the local government unit showed weak policy implementation.

In an effort to minimize the faults and negative effects of conventional tourism to the environment, ecotourism was used as an alternative form of tourism in many parts of the country. In 1991, the World Tourism Organization (WTO) together with the United Nations Development Programme (UNDP) collaborated with various government agencies and private organizations in the Philippines to make ecotourism a priority. However, it took eight years before an executive order that will structure its development was finally passed in 1999.

The Philippine Tourism Master Plan which aims to make the country a worldclass tourism destination was spearheaded by DOT. In 1992, the National Tourism Congress promoted the theme "ecotourism" in accordance to the principles of sustainable tourism development. The plan culminated through a technical workshop to develop a framework on how ecotourism projects in the Philippines can be best realized.

Community participation and involvement in projects and activities related to ecotourism are essential in achieving its sustainability and success. If people are involved from the very beginning of a project, they are more likely to support it and handle their parts or role in the project more enthusiastically. Other than gaining support, it also enables outside expert and managers to gain significant insights into local reality and knowledge that can help in arriving in a more relevant, effective, and sustainable project design (Mefalopulos, 2008) [2]. The key 
to effective participation is communication.

Communication enables the people to become aware of the things that may be of concern to them. It helps them gain access to information and other resources. Moreover, communication creates the link that binds people to a certain cause or purpose. Without communication, any human endeavor will likely fail. Anguga (1997) in Mefalopulos (2008) [2] noted that lack of participation and ineffective communication are two intertwined factors that are associated with failures and disappointments. The success and sustainability of an ecotourism project for the benefit of the people may therefore be measured by how effective the members of the community communicate and participate in the project as one of its stakeholders.

The participation of the community in the ecotourism projects in Caramoan, Camarines Sur is the primary concern of the present researcher, hence this study. It is important that the dynamics of community participation is understood in order to analyze its significance in sustaining or maintaning the ecotourism project in the site.

Generally, this study aimed to find out how the community participates in the eco-tourism project of the local government unit of Caramoan, Camarines Sur. Specifically, it sought to determine the socio-demographic characteristics of the respondents; determine the level of awareness of the respondents about the ecotourism project; determine the extent of participation of the respondents in the eco-tourism project; determine the nature of participation of the respondents about the ecotourism project; and determine the relationship between the respondents' socio-demographic characteristics, level of awareness, perceived role/s, and level of participation in the eco-tourism project.

The information generated from this research may guide other ecotourism project developers in planning, designing, implementing, and managing ecotourism projects which require the community involvement. The results of the study can provide them with information about how members of the community can be approached and mobilized to achieve certain goals. Insights generated from this research can also be of use to the community itself, for them to become more aware of what they are doing and what they can do for the sake of the project. This can hopefully make them realize their importance as stakeholders of the ecotourism industry in their locality.

\section{Literature Review}

\subsection{Community Participation for Sustainable Ecotourism}

One of the 13 underlying themes of ecotourism identified by Sirakaya et al. (1999) [3] in their study is community involvement. Based on this theme, ecotourism is a new form of tourism that encourages the active involvement of the local population.

According to Garrod (n.d.) [4] "at best, ecotourism projects tend to aim for the 'involvement' of local people, and even then the basis of such involvement is 
often tenuous. At worst, ecotourism projects can ignore the issue of local participation completely, excluding local people from the planning and management processes involved in developing ecotourism."

Carballo-Sandoval (1999) [5] noted that "participation of local communities in the development of sustainable ecotourism is viewed as a necessity." Boo (1991) and Simmons (1994) as cited by Carballo-Sandoval (1999) [5] both suggests that native communities are key components of a successful ecotourism project. Similarly, Rebuya (2020) [6] argued that community participation is one of the key approaches towards sustainable ecotourism and promotion of conservation of natural resources in a given area of ecotourism development. This may be true but unless these communities participate in ecotourism activities, they may be viewed otherwise.

To validate these assumptions, Carballo-Sandoval (1999) [5] conducted an ethnographic study to examine community participation as an essential element in sustainable ecotourism in three Mayan communities in the Mexican Caribbean area. He concluded that community participation in ecotourism projects in the areas is still young and underdeveloped and cannot be considered real and active. However, the community under study expressed high interest in the development of ecotourism. Furthermore, small and community-owned ecotourism activities generate three economic benefits such as 1) simpler and less expensive facilities; 2) increased input of local products, materials and labor; 3 ) and profits are directed to the local people.

To further understand the role of participation in ecotourism, it is important to know how the idea of participation emerged and how it is used and treated in other development initiatives.

Participation is a different approach that came to be when the modernization paradigm failed to realize its promise of achieving economic growth for underdeveloped countries and when the dependency paradigm failed to provide a successful alternative model for development. "This participatory model is less oriented to the political-economic dimension and more rooted in the cultural realities of development" (Mefalopulos, 2008) [2].

The participation model, moreover, represented a shift from economic growth as indicator of development to the inclusion of other social dimensions as a key to obtaining favorable results in the long run according to Mefalopulos (2008) [2]. The World Bank (1994) as mentioned by Mefalopulos, stated that the challenge of sustainable development has been given international emphasis and that participation is an important element of sustainable development strategies. Participation of members of the community is vital in development initiatives undertaken within an area. Participation allows for capacity-building, and ultimately empowers the community to be meaningfully involved in sustainable development of their area (Setokoe et al., 2019) [7].

In relation to that, Reid (2000) [8] noted some studies that show communities with high rates of participation apply for and receive more funding from agen- 
cies and organizations than communities with less participation. According to Reid, participation of the community is a requirement in USDAs programs specifically those which are geared towards people empowerment and that participation is critical in achieving success of the community. In addition, he stated that participation "is the heart that pumps the community's life blood-its citizens-into the community's business." Community participation, therefore, aids in mobilizing the people and empowering them to make decisions and actions necessary in attaining human and/or community development.

To participate means to take part or to become involved said Richardson (1983) [9]. On the other hand, Stoker (1997) [10] assumes public or community participation as "taking part in any of the processes of formulation, passage and implementation of public policies." According to Cecchini (2009) [11], the essence of participation is to make people exercise their voice and choice.

Participation or involvement in projects or activities varies from people to people and may be viewed in different ways (Mefalopulos, 2008) [2]. There are frameworks already made to classify community participation, the more prominent one includes Arnstein's Ladder of Participation (1969) which indicates the level by which people participates, Burn's Ladder of Citizen Empowerment (1994) which seeks to understand participation through empowerment of people and communities, and Wilcox' Ladder of Participation (1999), a modified version of Arnstein's which identifies the five interconnected levels of participation. In addition, Mefalopulos (2008) [2] also conceptualized a typology of participation that is compatible with others including the one used by the World Bank.

The role of community participation in development program projects has been explored by many researchers. Literature written by certain organizations such as the World Bank, USDA, and the Economic Commission for Latin Ameri$\mathrm{ca}$ and the Caribbean, describes participation as the key to the program or project's success. Reid (2000) [8] argues that community participation is far more than a requirement rather it is a condition for success. But still, some researchers are quite skeptical about it.

In 2008, Dzinavatonga conducted a study to evaluate the effectiveness of community participation in project sustainability in rural Zimbabwe. Results of the study indicated that the concept of community participation has been "undervalued" in the sense that development agents and governments chose not to practice it and "oversold" in such a way that they overemphasize it just to make it more enticing for international funding agencies to fund their respective projects.

Moreover, it was concluded that the process of community participation in the area was "redundant" in terms of project sustainability. This is because organizations impose their own kind of community participation to the people whose idea and understanding of community participation are different from them (Dzinavatonga, 2008) [12].

On the other hand, Sharma (2007) [13] attempted to qualitatively analyze the 
extent of evaluation of community participation in 22 community-based rehabilitation (CBR) studies evaluated over the last 30 years. Results of Sharma's study showed that of the 22 studies that evaluated CBR, only six evaluated community participation through assessing the participants' reaction to the project.

The effects of community participation vary among the six evaluations. Although, four out of six documented positive effects of participation while the other two showed that community participation has no effect or was inadequate in the CBR project.

Sharma, however, noted that more studies indicate that community participation is indeed desirable in projects. But still, "the number of studies done is very small to conclude for sure, that community participation always works. Morenumber of studies that measure community participation should be conducted beforefinal judgment can be passed on the utility of community participation," he furthered. He added that there is a need to develop more reliable and valid methods or measures to evaluate community participation. Moreover, other dimensions of community participation must be studied such as the measurement of the number of people with disabilities reached and quantity and quality of resources generated as a result of community participation.

\subsection{Factors Affecting Community Participation}

Enhanced community participation catalyzes the process of achieving optimum benefits for both the locals and tourism industry (Mubanga \& Umar, 2016) [14]. Recognizing the importance of community involvement, a number of researchers have tried to establish the factors that can stimulate the locals' participation in tourism-related activities. Salleh et al. (2016) [15] found out that the involvement of local communities in tourism-related business is influenced their income and encouragement from family as well as self-confidence, interest, and opportunity available in their area. Morever, Cheng et al. (2019) [16] determined that the "residents' attitudes towards sustainable tourism development positively and significantly affect both community participation and environmentally responsible behaviour."

The barriers to active community participation in tourism development have been reported in a plethora of researches in the field. There are four main obstacles to community participation in tourism development: practical, sociocultural, apprehension, and institutional (Kala \& Bagri, 2018) [17]. Mustapha (2013) [18] further classified these barriers into two types: internal (cultural), and external (operational and structural). An example of external barrier is the weather. Particularly, the rain limits the movement of the people thereby constricting their participation in tourism activities.

Towner (2016) [19] noted that foreign ownership and the lack of government support inhibits participation. Likewise, the study of Chili \& Ngxongo (2017) [20] also revealed the government's corruption, monopoly of resources and lack 
of dynamic leadership as factors that prohibit the community from participating in tourism development. Other challenges to community participation include lack of information and awareness among members of the community.

Bello et al. (2017) [21], identified apathy, inadequate financial resources, inadequate information, low education levels, unfair distribution of benefits, lack of trained human resources, a centralized public administration, lack of coordination, and human-wildlife conflicts as limiting factors to community involvement. According to Wondirad \& Ewnetu (2019) [22], communities' engagement in tourism development mainly depends on gatekeepers' nature and communities' economic background. They argued that it is hard to ensure community participation in areas that have manipulative gatekeepers and are economically poor.

Furthermore, Saufi \& Wilkins (2014) [23] reported that the three main institutional factors that hinder host community from participating in tourism development. These are state tourism agencies, the private sector providers and tourism infrastructure, and their perceptions on the negative impacts of tourism to their respective communities. They argued that poor tourism infrastructure as a result of the underperformance of state and private tourism agencies/providers limits the opportunities for involvement of local community.

To improve community participation in tourism development, Towner (2016) [19] suggested that education and capacity building is the most effective way to achieve full and active community participation. This is supported by Bello et al. (2018) [24] who identified four more strategies to enhance community involvement. These are creation of linkages; use of appropriate participation methods; involvement of appropriate local community organisations and decentralisation and coordination of relevant management organisations.

\subsection{Related Studies}

Guttierez (2019) [25] investigated the level of community participation in three community-based tourism (CBT) initiatives in the Philippines, the El Nido Resorts, the Bojo Aloguinsan Ecotourism Association, and the Kawit Community-Based Heritage Tourism using Arnstein (1969)'s Ladder of Citizen Participation. Findings revealed that the level of community participation in tourism activities and development in the three cases differs and continuously evolves. The local community in El Nido is consulted prior to policy formation or implementation. They are considered as partners in tourism iniatives. In the case of Kawit Community-Based Heritage Tourism (CBHT), Guttierez observed that participation falls in between partnership and delegated power. According to Arnstein's participation ladder, this level of participation can be classified as local community having citizen power. The local community negotiates with authorities when it comes to planning and decision making. Residents are also able to facilitate their own tours without government support. Finally, in Bojo Aloguinsan Ecotourism Association (BAETAS), community participation can be categorized 
into eight stages with "citizen control" as the highest stage.

On the other hand, Moyo and Tichaawa (2017) [26] conducted a study on the extent of community involvement and participation in the tourism development trajectory within the urban community of Bulawayo, Zimbabwe. Through faceto-face survey with 384 households, they found out that communities do not adequately participate in tourism development in terms of planning, decision making and other activities.

Morevoer, Mak et al. (2017) [27], in their study on the level of community participation in the context of urban tourism, deduced that there is a difference between the residents' expected and actual involvement in tourism development. They noted that local residents are not well aware of public consultation activities and the schedules are not convenient for them.

\subsection{Conceptual Framework}

This study aims to find out the extent of community participation in the ecotourism project of the local government unit of Caramoan.

The extent or level of participation is measured based on Pretty's Typology of Participation (1995) [28]. The levels of participation as indicated by Pretty are Self-Mobilization, Interactive Participation, Functional Participation, Participation for Material Incentives, Participation by Consultation, Participation in Information-giving, and Passive Participation. Table 1 provides these levels of participation and its descriptions.

Furthermore, the relationship of the independent variables (socio-demographic characteristics, level of awareness of the ecotourism project, and communication methods applied by the project proponents to approach and mobilize the respondents) with the dependent variables (perceived roles, nature of participation, and level of participation of the communities) was determined for this study. Figure 1 presents the conceptual framework of the study.

\section{Methodology}

The research method used in this study is quantitative in nature. Specifically, it employed the survey technique to collect the data needed. Survey questionnaires were given to selected respondents in self-administered forms.

\subsection{Locale of the Study}

Caramoan is a 2nd class municipality located at the tip of the Caramoan Peninsula in the province of Camarines Sur. It is about 95 kilometers away from the provincial capital and is subdivided into 49 barangays. It covers approximately 27,741 square kilometers of land with approximately 71 kilometers of irregular coastline surrounded by vast ocean, bay, seas, and swamps. According to the Philippine Statistics Office (PSA), it has a population of 47, 605 as of 2015 which is about $2.44 \%$ of the total population of Camarines Sur. 
Table 1. Pretty's typology of participation.

\begin{tabular}{|c|c|}
\hline Typology & Description \\
\hline Self-Mobilization & $\begin{array}{l}\text { People participate by taking initiatives independent of external } \\
\text { institutions to change systems. Such self-initiated mobilization } \\
\text { and collective action may or may not challenge existing } \\
\text { inequitable distributions of wealth and power. }\end{array}$ \\
\hline $\begin{array}{c}\text { Interactive } \\
\text { Participation }\end{array}$ & $\begin{array}{l}\text { People participate in joint analysis which leads to action plans } \\
\text { and the formation of new local groups or the strengthening of } \\
\text { existing ones. It tends to involve interdisciplinary methodologies } \\
\text { that seek multiple perspectives and make use of systematic and } \\
\text { structured learning processes. These groups take control over } \\
\text { local decisions, and so people have a stake in maintaining } \\
\text { structures and practices. }\end{array}$ \\
\hline $\begin{array}{l}\text { Functional } \\
\text { Participation }\end{array}$ & $\begin{array}{l}\text { People participate by forming groups to meet predetermined } \\
\text { objectives related to the project, which can involve the } \\
\text { development or promotion of externally initiated social } \\
\text { organization. Such involvement does not tend to be at early } \\
\text { stages of project cycles or planning, but rather after major } \\
\text { decisions have been made. These institutions tend to be } \\
\text { dependent on external initiators and facilitators but may } \\
\text { become self-dependent. }\end{array}$ \\
\hline $\begin{array}{l}\text { Participation for } \\
\text { Material Incentives }\end{array}$ & $\begin{array}{l}\text { People participate by providing resources, for example labor, } \\
\text { in return for food, cash or other material incentives. Much } \\
\text { in-situ research and bio-prospecting fall in this category, } \\
\text { as rural people provide the resources but are not involved } \\
\text { in the experimentation or the process of learning. It is very } \\
\text { common to see this called participation, yet people have } \\
\text { no stake in prolonging activities when the incentives end. }\end{array}$ \\
\hline $\begin{array}{c}\text { Participation by } \\
\text { Consultation }\end{array}$ & $\begin{array}{l}\text { People participate by being consulted, and external agents } \\
\text { listen to views. These external agents define both problems } \\
\text { and solutions and may modify these in the light of people's } \\
\text { responses. Such a consultative process does not concede } \\
\text { any share in decision-making and professionals are under } \\
\text { no obligation to take on board people's views. }\end{array}$ \\
\hline $\begin{array}{l}\text { Participation in } \\
\text { Information-giving }\end{array}$ & $\begin{array}{l}\text { People participate by answering questions posed by extractive } \\
\text { researchers and project managers using questionnaire surveys } \\
\text { or similar approaches. People do not have the opportunity } \\
\text { to influence proceedings, as the findings of the research or } \\
\text { project design are neither shared nor checked for accuracy. }\end{array}$ \\
\hline $\begin{array}{c}\text { Passive } \\
\text { Participation }\end{array}$ & $\begin{array}{l}\text { People participate by being told what is going to happen or } \\
\text { what has already happened. It is unilateral announcement } \\
\text { by an administration or by project management; people's } \\
\text { responses are not taken into account. The information } \\
\text { being shared belongs only to external professionals. }\end{array}$ \\
\hline
\end{tabular}

Source: Pretty, J.N. 1995. Regenerating Agriculture: Policies and Practice for Sustainability and Self-Reliance. Earthscan, London; National Academy Press, Washington adapted from Adnan et al. 1992. 
INDEPENDENT VARIABLES

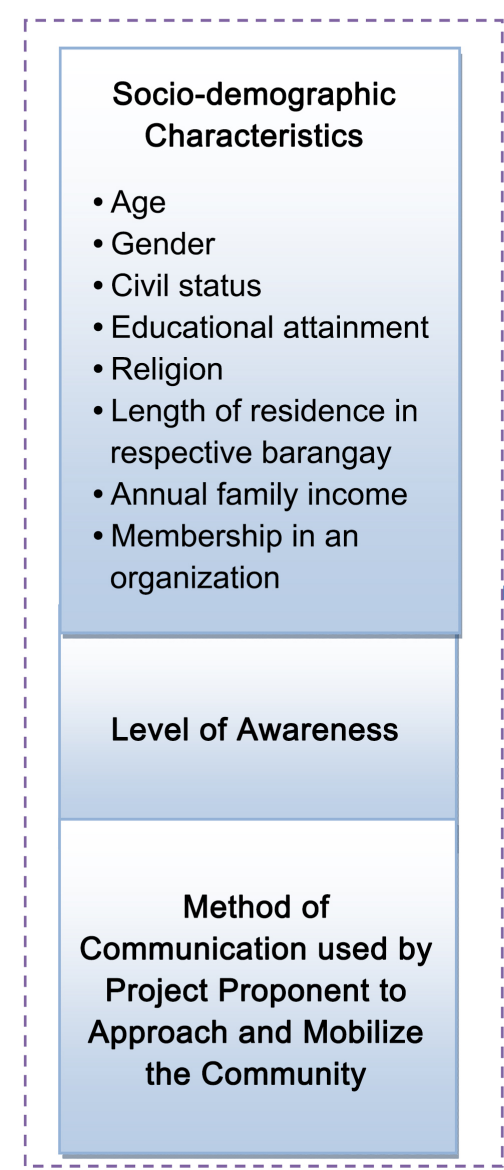

DEPENDENT VARIABLES

Perceived Role and Nature of Participation

Level of Participation

- Self-Mobilization

- Interactive Participation

- Functional Participation

- Participation for Material Incentives

- Participation by

Consultation

- Participation in Information-giving

- Passive Participation

Figure 1. Conceptual framework showing the relationship between and among the variables of the study.

The present study focused on Barangay Paniman, one of Caramoan's 49 barangays, since it serves as the main gateway to the town's many ecotourism activities, mainly the island hopping tours. Barangay Paniman is a fishing village but due to the emerging ecotourism industry in the place, some of the residents there chose to convert their houses to accommodation facilities for tourists.

\subsection{Respondents and Sampling Procedure}

A sample of 97 households from Barangay Paniman, Caramoan, Camarines Sur was randomly chosen to give each household an equal chance of being included in the study. A household refers to people belonging to a family who are living in one house, sharing the same food, and are registered under one name in the barangay's list (Obua et al., 1998) [29].

Due to the large number of community members to be surveyed, only the household heads were chosen to be the respondents of the study.

\subsection{Research Instrument}

A formulated self-administered questionnaire was used to gather the necessary 
data from the chosen respondents. The questionnaire was composed of five parts. The first part dealt on the socio-demographic characteristics of the respondents. Parts two, three, four, and five provided information on the perceived level of awareness; communication methods used to approach and mobilize the respondents; perceived role/s; and the nature and level of participation, respectively. These items were derived from the Pretty's typology of participation and related review of studies and literatures. This survey instrument has undergone a reliability and consitency test using Cronbach's Alpha and was tested through dry-run to a sample respondents prior to the actual data gathering.

The research questionnaire was distributed personally by the researcher and an assistant. The purpose of the study and contents of the questionnaire were explained to the respondents prior to answering it.

Furthermore, a semi-structured interview with the head of the project was done to gather relevant data from the key informant. Questions about the project itself and how the respondents were approached and mobilized were asked by the researcher to the project head.

\subsection{Data Collection/Gathering Procedure}

This study was carried out using the three methods of data collection such as the following: 1) the mothers/fathers belonging in the sample were asked to answer a self-administered questionnaire; 2) key informants such as the project head and barangay captain were interviewed; 3) and existing documents about the community and the ecotourism project from the barangay, municipal, and provincial government were analysed.

\subsection{Data Analysis}

Both descriptive and quantitative statistics were used in the data analysis. Descriptive statistics such as frequency counts, percentages, and means were used in analysing the socio-demographic characteristics, perceived level of awareness; communication channels, methods, and messages used to approach and mobilize the respondents; perceived role/s; and the nature and level of participation, respectively. Data on the nature and level of participation were obtained using the Likert-type scale and were measured using weighted mean (Table 2).

Table 2. Weighted mean interval and qualitative interpretation of responses.

\begin{tabular}{cc}
\hline Range & Interpretation \\
\hline $4.50-5.00$ & Strongly Agree \\
$3.50-4.49$ & Agree \\
$2.50-3.49$ & Neutral \\
$1.50-2.49$ & Disagree \\
$1.00-1.49$ & Strongly Disagree \\
\hline
\end{tabular}


On the other hand, the Chi-square test of independence was used to determine the relationship between the respondents' socio-demographic characteristics, level of awareness, perceived roles, and level of participation in the ecotourism project.

\section{Results and Discussion}

\subsection{Socio-Demographic Characteristics of Respondents}

Table 3 presents the socio-demographic characteristics of the household heads of barangay Paniman in Caramoan, Camarines Sur.

Table 3. Respondents' socio-demographic characteristics.

\begin{tabular}{|c|c|c|}
\hline Characteristics & Frequency & Percentage \\
\hline \multicolumn{3}{|l|}{ Age } \\
\hline $18-25$ & 13 & 13.40 \\
\hline $26-33$ & 19 & 19.59 \\
\hline $34-41$ & 30 & 30.93 \\
\hline $42-49$ & 24 & 27.74 \\
\hline $50-57$ & 4 & 4.12 \\
\hline $58-65$ & 4 & 4.12 \\
\hline $66-73$ & 2 & 2.06 \\
\hline $74-81$ & 1 & 1.03 \\
\hline \multicolumn{3}{|l|}{ Gender } \\
\hline Male & 74 & 76.29 \\
\hline Female & 23 & 23.71 \\
\hline \multicolumn{3}{|l|}{ Civil Status } \\
\hline Married & 67 & 69.07 \\
\hline Single & 27 & 27.84 \\
\hline Widowed & 2 & 2.06 \\
\hline Separated & 1 & 1.03 \\
\hline \multicolumn{3}{|l|}{ Educational Attainment } \\
\hline Elementary level & 7 & 7.22 \\
\hline Elementary Graduate & 5 & 5.15 \\
\hline High School Level & 4 & 4.12 \\
\hline High School Graduate & 38 & 39.18 \\
\hline College Level & 15 & 15.46 \\
\hline College Graduate & 23 & 23.71 \\
\hline Vocational Course & 3 & 3.09 \\
\hline Master's Degree & 1 & 1.03 \\
\hline Not Stated & 1 & 1.03 \\
\hline
\end{tabular}




\section{Continued}

\begin{tabular}{|c|c|c|}
\hline \multicolumn{3}{|l|}{ Religion } \\
\hline Roman Catholic & 92 & 94.85 \\
\hline Iglesia ni Cristo & 2 & 2.06 \\
\hline Protestant & 2 & 2.06 \\
\hline Born Again Christian & 1 & 1.03 \\
\hline \multicolumn{3}{|c|}{ Length of stay in barangay, in years } \\
\hline Below 10 & 11 & 11.34 \\
\hline $10-19$ & 13 & 13.40 \\
\hline $20-29$ & 20 & 20.62 \\
\hline $30-39$ & 20 & 20.62 \\
\hline $40-49$ & 26 & 26.80 \\
\hline $50-59$ & 4 & 4.12 \\
\hline Above 60 & 3 & 3.09 \\
\hline \multicolumn{3}{|l|}{ Family Size } \\
\hline $1-5$ & 42 & 43.29 \\
\hline $6-10$ & 51 & 52.58 \\
\hline $11-15$ & 3 & 3.09 \\
\hline Not stated & 1 & 1.0 \\
\hline \multicolumn{3}{|c|}{ Annual Family Income, in $\mathrm{PhP}$} \\
\hline 10,000 and below & 22 & 22.68 \\
\hline $10,001-30,000$ & 23 & 23.71 \\
\hline $30,001-50,000$ & 20 & 20.62 \\
\hline $50,001-70,000$ & 2 & 2.06 \\
\hline $70,001-90,000$ & 1 & 1.03 \\
\hline 90,001 and above & 15 & 15.46 \\
\hline Not Stated & 14 & 14.43 \\
\hline \multicolumn{3}{|l|}{ Membership in organization/s } \\
\hline BTO & 18 & 32.73 \\
\hline $\mathrm{BBOA}$ & 17 & 30.91 \\
\hline Barangay Council & 5 & 9.10 \\
\hline Knights of Columbus & 1 & 1.82 \\
\hline 4 P's & 5 & 9.10 \\
\hline PPTODA & 2 & 3.64 \\
\hline Tau Gamma Phi & 1 & 1.82 \\
\hline Tourism Office & 1 & 1.82 \\
\hline Van org & 1 & 1.82 \\
\hline Women's Org. & 1 & 1.82 \\
\hline Youth for Christ & 1 & 1.82 \\
\hline
\end{tabular}




\subsubsection{Age}

The age range of the respondents was quite broad. They were a mixture of the young and the old. Minimum age was 18 years and maximum was 74 years with the average age of 38.27 years. Almost one third of the respondents (31\%) belong to the $34-41$ years age group which was usually the age when one is expected to already have a family. It was followed by the $42-49$ years age group with 28 percent (24 out of 97) of the respondents belonging in it.

\subsubsection{Gender}

Majority of the respondents were males (76\%) while females only comprised the remaining 24 percent of the total number of respondents. This is because males specifically the father or the eldest son is usually considered as the head of the family or the household. Females take the part of the household head only in the absence of the males.

\subsubsection{Civil Status}

Most of the respondents were married (69\%). The other 31 percent were either single, widowed, or separated respondents. This means that most of them already have families of their own and were working to provide for their family.

\subsubsection{Educational Attainment}

Table 3 indicates that the respondents were composed mostly of those who graduated in high school but did not continue on to college (39\%). This may be attributed to the absence of a university or a school offering tertiary education in the municipality before. Also, the respondents would rather work to earn a living than to pursue higher education.

On the other hand, 15 percent of the respondents pursued college and 24 percent already finished tertiary education. The other few were distributed among those who were in elementary level (7\%), those who graduated in elementary (5\%), those who took vocational courses (3\%), and those who took up graduate studies (1\%).

\subsubsection{Religion}

Almost all of the respondents were Roman Catholics (95\%). However, there were also very few who belong to other religions. One of them was a Born Again Christian, two were Protestants, and the other two were members of the Iglesia ni Cristo. This result implies that almost all of the residents of the barangay share the same faith and believes in the same religion.

\subsubsection{Length of Stay in Barangay}

Majority of the respondents stated that they stayed or lived in their respective barangays since birth. Data revealed that the average length of stay was 31.11 years with the maximum of 74 years which was equivalent to the age of the oldest respondent.

However, the minimum length of stay as indicated by one of the respondents was seven months. Table 3 shows that 27 percent spent $40-49$ years in their 
barangay (27\%). This was followed by 20 - 29 and 30 - 39 years with 21 percent respondents staying in their barangay for that length of time.

\subsubsection{Family Size}

The average family size for the respondents was six to ten with $53 \%$. Less than half $(43 \%)$ of the respondents have a family size smaller than the average or one to five while a little less than one-third (34\%) of the total number of respondents had more than six family members in their household. The average family size of the respondents is slightly greater than the average Filipino family size of five.

\subsubsection{Annual Family Income}

Twenty-four percent (23 out of 97) of the respondents, had an annual family income of Php10,001 - 30,000, followed by those with Php10,000 and below (23\%), and Php30,001 - 50,000 (21\%), respectively. A very small fraction had an annual family income of Php50,001 - 70,000 (2\%) and Php70,001 - 90,000 (1\%) while 15 percent stated that they earn up to Php90,001 and more yearly. A large part of their income came from fishing and from providing tourism services such as transportation mainly through rental of boats, vans, and tricycles; selling of souvenirs; and rental of swimming equipment. The annual family income of the respondents (Php10,000 - 30,000) reflected those of the majority of Filipino families (76.7\%) who earn an average of Php64,649 a year (Virola et al., 2007). These families including that of the respondents belong to the low-income group.

\subsubsection{Membership in Organizations}

Of the 97 respondents, more than half $(55 \%$ or $57 \%)$ were affiliated with at least one organization while the other 42 percent did not belong to any organization. Of the 55 respondents with organizations, one third (33\%) are members of the Barangay Tourism Officers (BTO) while another almost one third (31\%) of them belong to the Barangay Boat Operators Association (BBOA).

$\mathrm{BTO}$ and $\mathrm{BBOA}$ are organizations directly involved in the ecotourism project. They are composed of male residents of Paniman who are working for the municipal tourism office to provide assistance to tourists for their tourism activities. Membership in these organizations, thus, provides a direct link between the individuals and the Ecotourism project. The involvement and participation of these individuals may then be dictated and imposed by the organization that they belong to.

\subsection{Respondents' Level of Awareness and Sources of Information Regarding the Ecotourism Project}

\subsubsection{Level of Awareness}

Table 4 shows the level of respondents' awareness of the project. All of them were aware of the project being implemented by the Municipal Tourism Office. However, a small fraction of respondents (4\%) believed that they were only somehow aware of it which means that they were not that particular about its details. They only knew that the project exists because of the ecotourism indus- 
try. On the other hand, quite a number of them (28\%) responded that they were indeed very aware of the project. Answers from the survey questionnaires revealed that, the "very aware" response was common among the respondents who were directly involved in the project which included some staff of the municipal tourism office, the boat operators, and the boat captains among others.

\subsubsection{Sources of Information}

It was found out that most of the respondents came to know about the project through public announcements and through word of mouth, respectively (Table 4). Specifically, 52 percent of them learned about the existence of such project because the municipal and barangay office announced it and the other 45 percent were told about it by their family, relatives, friends, and neighbors among others. Electronic sources of information such as the television $(20 \%)$, internet $(11 \%)$, and radio (5\%) received lower percentages and only 7 percent of the respondents found about the project through the newspaper. Other information sources together with those mentioned above are shown in Table 5.

Table 4. Respondents' level of awareness of the ecotourism project.

\begin{tabular}{ccc}
\hline Level & Frequency $(\mathbf{N}=\mathbf{9 7})$ & Percentage (\%) \\
\hline Aware & 66 & 68.04 \\
Very aware & 27 & 27.84 \\
Somehow aware & 4 & 4.12 \\
Unaware & 0 & 0.00 \\
\hline
\end{tabular}

Table 5. Respondents' sources of information.

\begin{tabular}{lcc}
\hline \multicolumn{1}{c}{ Sources } & Frequency $(\mathbf{N}=\mathbf{9 7})^{*}$ & Percentage (\%) \\
\hline 1) Interpersonal sources & & \\
Through acquaintances & 44 & 45.36 \\
Through WWF & 2 & 2.06 \\
Educated by employer & 2 & 2.06 \\
Through trainings & 2 & 2.06 \\
Through primary stakeholders & 1 & 1.03 \\
\hline 2) Media Sources & & \\
Public announcements & 50 & 51.55 \\
Television & 19 & 19.59 \\
Internet & 11 & 11.34 \\
Newspaper & 7 & 7.22 \\
Radio & 5 & 5.15 \\
\hline
\end{tabular}

${ }^{\star}$ Multiple response. 
This implies that the respondents rely heavily on government announcements and words of other people in acquiring information about certain things. It may mean that respondents consider the government and the people they know of as more reliable sources of information than other interpersonal and media sources. However, according to a study done by Ricaforte (2010) [30], broadsheets contribute to industry involvement and the marketing and promotion of ecotourism. Broadsheet and/or newspaper as an information source of the respondents received the lowest percentage in the survey.

\subsubsection{Duties and Responsibilities of Respondents}

Table 6 reveals the duties and responsibilities of the respondents as set by the project proponents. It was found out that 20 percent were tasked to assist visitors and tourist while 17 percent saw their responsibilities in attending orientations, trainings, and seminars regarding the project. Such result can be attributed to the fact that the ecotourism industry in the area mainly requires a number of people to help in assisting tourists and visitors.

Table 6. Respondents' duties and responsibilities for the project.

\begin{tabular}{|c|c|c|}
\hline Duties & Frequency $(n=46)^{*}$ & Percentage (\%) \\
\hline To assist visitors and tourists & 9 & 19.57 \\
\hline $\begin{array}{l}\text { To attend orientations, trainings and } \\
\text { seminars regarding the project }\end{array}$ & 8 & 17.39 \\
\hline To become a boat operator & 4 & 8.70 \\
\hline To become a boat captain & 3 & 6.52 \\
\hline $\begin{array}{l}\text { To help in cleaning the municipal tourism } \\
\text { office and its surroundings }\end{array}$ & 2 & 4.35 \\
\hline $\begin{array}{l}\text { To help protect the fish sanctuary and } \\
\text { support the eco-tourism itself }\end{array}$ & 2 & 4.35 \\
\hline To be a boat operator & 1 & 2.17 \\
\hline To give opinions regarding resolutions & 2 & 4.34 \\
\hline $\begin{array}{c}\text { To provide service as an underwater } \\
\text { videographer }\end{array}$ & 2 & 4.34 \\
\hline $\begin{array}{l}\text { To be trained and oriented with the } \\
\text { ecotourism operations/activities }\end{array}$ & 1 & 2.17 \\
\hline To become a life saver & 2 & 4.34 \\
\hline To provide ecotourism services & 2 & 4.34 \\
\hline To serve as a diver & 2 & 4.34 \\
\hline $\begin{array}{l}\text { To support, protect the ecotourism site, } \\
\text { maintain cleanliness }\end{array}$ & 1 & 2.17 \\
\hline No response & 5 & 10.87 \\
\hline
\end{tabular}

${ }^{\star}$ Multiple response. 
Moreover, attending orientations and seminars regarding the project was also seen to be a responsibility of the people since the Municipal Tourism Office needed to be ensured that the person they will hire for the job of assisting the tourists and visitors is well-educated about ecotourism protocols which are very important in maintaining the proper condition of the area.

\subsection{Respondents' Perceived Roles and Nature of Participation}

Roles help define the kind of participation one can have in a certain project. In this study, the perceived roles of the respondents were determined and presented in this part. The perceived role simply pertains to the assumed social behavior or function associated with the position and status of the community members.

\subsubsection{Perceived Roles}

Results of the survey revealed that almost half of the respondents (49\%) consider themselves as concerned citizen only (Table 7). This means that their function in the project is limited only on their decision whether to be directly involved in the project or not. They are not obliged or required to do things for the project unless they want to.

Moreover, more than one third (38\%) of the respondents said that they are members of organizations directly involved in the project. Eleven of them assumed the role of staff member while six are leaders of those involved organizations.

Table 8 presents the number of years the respondents had been assuming their roles in the project. The maximum number of years is 14 while the minimum is 3 months. Twenty-five percent of the respondents believe that they were assuming their roles for 3 - 5 years while another 23 percent said that they were assuming their roles for about $12-14$ years.

Table 7. Perceived roles of the respondents in the project.

\begin{tabular}{ccc}
\hline Perceived Role & Frequency $(\mathrm{N}=\mathbf{9 7})^{*}$ & Percentage (\%) \\
\hline $\begin{array}{c}\text { Concerned citizen } \\
\begin{array}{c}\text { Member of an organization directly } \\
\text { involved in the project }\end{array}\end{array}$ & 48 & 49.48 \\
$\quad$ Staff member & 11 & 38.14 \\
$\begin{array}{c}\text { Leader of an organization directly } \\
\text { involved in the project }\end{array}$ & 6 & 11.34 \\
None & 6 & 6.19 \\
LGU & 3 & 6.19 \\
Client/Beneficiary of tourism services & 3 & 3.09 \\
Municipal Tourism Office employee & 3 & 3.09 \\
Food and room service provider & 1 & 3.09 \\
Dive master & 1 & 1.03 \\
\hline
\end{tabular}

${ }^{\star}$ Multiple response. 
Table 8. Number of year respondents assumed their roles in the project.

\begin{tabular}{ccc}
\hline Years & Frequency $(\mathbf{N}=\mathbf{9 7})$ & Percentage (\%) \\
\hline 2 and below & 10 & 10.31 \\
$3-5$ & 24 & 24.74 \\
$6-8$ & 9 & 9.28 \\
$9-11$ & 4 & 4.12 \\
$12-14$ & 22 & 22.68 \\
Not Stated & 20 & 20.62 \\
Not Applicable & 8 & 8.25 \\
\hline
\end{tabular}

With just 3 - 5 years of assuming respective roles, it can be implied that the respondents had not participated in the project all throughout its duration which is about 14 years since its establishment. It may also mean that the respondents had just recently started participating or getting involved in the project for reasons known only to them.

\subsubsection{Nature of Participation}

In general, respondents saw themselves as someone who can help in the ecotourism project. With this statement, it can be implied that they considered themselves capable of doing things that can contribute to the development of the project. And since they believed that they can be of help to the project, they took part and were involved in any of its activities or operations. The same results were found by Thetsane (2019) [31] in her study on the expected nature of local community participation in tourism development and Lekaota (2015) [32].

Moreover, the respondents considered themselves as an information source, project proponents can get and extract relevant information regarding the ecotourism project from them such as the most affordable mode of transportation to get to the site, water safety, and the likes (Table 9).

However, when it comes to leadership, respondents were found to be neutral. They did not consider themselves as leaders of the project but they also believe that they act as leaders who manage some operations of the project. They also thought the same way about being a supervisor who watches over some of the project's operations. This is again consistent with Thetsane's (2019, p. 132) [31] findings that residents reject the idea of them taking the "lead role as workers at all levels."

In line with the previous observations, it can be confirmed that the respondents were more of the follower rather than the leader. They usually followed what the project proponents told them to do such as attending meetings, going on-site to assist tourists or visitors or offer tour services, and the likes. They also acted and carried on the decisions made for the project. Likewise, they were neutral when it comes to making decisions regarding the program such as the management system, allocation of funds, etc. They were neither agreeing nor disagreeing on the assumption that they included themselves or they were really included in those who made certain decisions for the project. 
Table 9. Nature of respondents' participation.

\begin{tabular}{|c|c|c|c|c|c|c|c|}
\hline Statements & SD & $\mathrm{D}$ & $\mathbf{N}$ & A & SA & $\begin{array}{l}\text { Weighted } \\
\text { Mean }\end{array}$ & $\begin{array}{l}\text { Interpre } \\
\text { Tation }\end{array}$ \\
\hline $\begin{array}{l}\text { I see myself as someone who can help in the } \\
\text { ecotourism project. }\end{array}$ & 0 & 1 & 4 & 45 & 47 & 4.42 & Agree \\
\hline $\begin{array}{l}\text { I do not take part in the project. I am not involved } \\
\text { in any activities or operations of the project. }\end{array}$ & 16 & 54 & 7 & 16 & 4 & 2.36 & Disagree \\
\hline $\begin{array}{l}\text { I can be the one whom project proponents can get } \\
\text { relevant information such as most affordable mode } \\
\text { of transportation to get to the site, water safety, } \\
\text { and the likes. }\end{array}$ & 4 & 15 & 7 & 51 & 20 & 3.70 & Agree \\
\hline $\begin{array}{l}\text { I act as one of the leaders who manage some } \\
\text { of the operations regarding the project. }\end{array}$ & 8 & 44 & 14 & 22 & 9 & 2.79 & Neutral \\
\hline $\begin{array}{l}\text { I supervise/oversee/watch over some of the } \\
\text { operations regarding the project. }\end{array}$ & 9 & 29 & 16 & 28 & 15 & 3.11 & Neutral \\
\hline $\begin{array}{l}\text { I usually do what I am told to do by the project } \\
\text { proponents such as attending meetings, going } \\
\text { on-site to assist tourists or visitors or offer tour } \\
\text { services, and the likes. }\end{array}$ & 5 & 15 & 10 & 32 & 35 & 3.79 & Agree \\
\hline $\begin{array}{l}\text { I participate in making certain decisions for the } \\
\text { project which includes the management system, } \\
\text { allocation of funds, etc. }\end{array}$ & 10 & 27 & 13 & 32 & 15 & 3.15 & Neutral \\
\hline I act and carry on the decisions made for the project. & 7 & 17 & 11 & 37 & 25 & 3.58 & Agree \\
\hline $\begin{array}{l}\text { I am directly involved in the project as boat operator, } \\
\text { tour guide, and life guard. }\end{array}$ & 10 & 24 & 10 & 13 & 40 & 3.51 & Agree \\
\hline $\begin{array}{l}\text { I benefit or will benefit from the project if it is } \\
\text { successful. }\end{array}$ & 3 & 12 & 13 & 38 & 31 & 3.85 & Agree \\
\hline
\end{tabular}

Lastly, it was also revealed that respondents participated as beneficiaries of the project. They were currently receiving benefits or will be benefitted once the project becomes a success.

\subsection{Level of Participation}

To assess the level of participation of the respondents, Pretty's Typology of Participation was used as reference for constructing the statements that served as indicators for each of the seven types of participation.

Respondents agreed, in general, with the first to third statements in the Likert scale type that was used to analyze their level of participation as identified by Pretty. The first three statements which gained weighted means of 3.69, 3.66 and 3.65 respectively in Table 10 are related to the first three levels of community participation which are passive participation, participation in information-giving and participation by consultation. 
Table 10. Level of respondents' participation.

\begin{tabular}{|c|c|c|c|c|c|c|c|}
\hline Statements & SD & $\mathrm{D}$ & $\mathbf{N}$ & A & SA & $\begin{array}{l}\text { Weighted } \\
\text { mean }\end{array}$ & $\begin{array}{l}\text { Interpre } \\
\text { Tation }\end{array}$ \\
\hline $\begin{array}{l}\text { I am informed about what is going to happen or } \\
\text { what has happened regarding the ecotourism } \\
\text { project by the project proponents. }\end{array}$ & 5 & 17 & 6 & 44 & 25 & 3.69 & Agree \\
\hline $\begin{array}{l}\text { I sometimes answer the questions about the } \\
\text { ecotourism project asked to me by the project } \\
\text { proponents or managers through a survey, } \\
\text { interview, or other similar approaches. }\end{array}$ & 4 & 17 & 6 & 51 & 19 & 3.66 & Agree \\
\hline $\begin{array}{l}\text { I often give feedback in the form of opinions and/or } \\
\text { reactions about the project whenever I am asked to. }\end{array}$ & 4 & 20 & 4 & 47 & 22 & 3.65 & Agree \\
\hline $\begin{array}{l}\text { I am usually consulted by the project proponents or } \\
\text { managers whenever there is a need to. I express my } \\
\text { views, ideas, opinions, or sentiments to them. }\end{array}$ & 13 & 21 & 8 & 36 & 19 & 3.28 & Neutral \\
\hline $\begin{array}{l}\text { I provide service or work for the project so that } \\
\text { I will have an income. }\end{array}$ & 14 & 18 & 11 & 28 & 26 & 3.35 & Neutral \\
\hline $\begin{array}{l}\text { I receive food and other materials from the project } \\
\text { proponents or managers for what I have done or } \\
\text { what I am doing for the project. }\end{array}$ & 15 & 25 & 16 & 28 & 13 & 2.99 & Neutral \\
\hline $\begin{array}{l}\text { I am a member of a group or organization formed } \\
\text { to help realize the goals and objectives of the } \\
\text { project set by the project proponents. }\end{array}$ & 12 & 24 & 13 & 26 & 22 & 3.23 & Neutral \\
\hline $\begin{array}{l}\text { I am involved in the setting of goals and } \\
\text { objectives of the project. }\end{array}$ & 9 & 31 & 12 & 30 & 15 & 3.11 & Neutral \\
\hline $\begin{array}{l}\text { I am involved in identifying the problems that the } \\
\text { project is encountering or will be encountering such } \\
\text { as lack of manpower, funds and other resources, being } \\
\text { unable to achieve certain objectives, and the likes. } \\
\text { I am also involved in figuring out the solutions to it. }\end{array}$ & 12 & 27 & 8 & 32 & 18 & 3.18 & Neutral \\
\hline $\begin{array}{l}\text { I am involved in the formulation of action } \\
\text { plans for the ecotourism project. }\end{array}$ & 15 & 24 & 17 & 24 & 17 & 3.04 & Neutral \\
\hline $\begin{array}{l}\text { I am part of those who make the decisions and } \\
\text { implement them for the ecotourism project. }\end{array}$ & 14 & 33 & 18 & 21 & 11 & 2.81 & Neutral \\
\hline $\begin{array}{l}\text { I usually act on my own initiative. I do not wait for the } \\
\text { project proponents or managers to tell me what to do. }\end{array}$ & 12 & 30 & 20 & 25 & 10 & 2.91 & Neutral \\
\hline $\begin{array}{l}\text { I regularly attend discussions and/or meetings } \\
\text { regarding the project set by the project proponents. }\end{array}$ & 9 & 18 & 12 & 18 & 40 & 3.64 & Agree \\
\hline $\begin{array}{l}\text { I usually express my ideas during those } \\
\text { discussions and/or meetings. }\end{array}$ & 7 & 26 & 9 & 26 & 29 & 3.45 & Neutral \\
\hline I help in managing the resources of the project. & 16 & 26 & 17 & 25 & 13 & 2.93 & Neutral \\
\hline $\begin{array}{l}\text { I take part in all the processes of the ecotourism } \\
\text { project from planning to evaluation of the project. }\end{array}$ & 10 & 33 & 19 & 20 & 15 & 2.97 & Neutral \\
\hline
\end{tabular}


Meanwhile, respondents gave neutral responses on all of the succeeding statements which reflected Pretty's fourth to seventh levels of participation except for one. They only agreed on the statement that said they regularly attend discussions and/or meetings regarding the project set by the project proponents which was basic for all those who were involved in the project.

\subsection{Relationship between Variables}

\subsubsection{Socio-Demographic Characteristics and Level of Awareness}

Chi-square results showed that there was no relationship between the respondents' socio-demographic profile and their level of awareness of the ecotourism project at $5 \%$ level of significance (Table 11). This means that the respondents' levels of awareness on the project do not depend on their socio-demographic characteristics.

\subsubsection{Socio-Demographic Characteristics and Nature of Participation}

Chi-square results showed that there was no relationship between the respondents' age, educational attainment, number of years living in the barangay, and family size since the equivalent $\mathrm{p}$-values are greater than the 0.05 level of significance (Table 12).

However, there was evidence to say that the nature of participation of the respondents are related to their gender, civil status, religion, annual family income and being a member of an organization since equivalent $p$-values for corresponding socio demographic profiles are less than the said alpha. These certain socio-demographic characteristics have significant effects on the way the respondents participate in the project.

Table 11. Summary of Pearson Chi-Square Value between respondents' socio-demographic characteristic and level of awareness of the ecotourism project.

\begin{tabular}{cccc}
\hline Variables & $\begin{array}{c}\text { Pearson } \\
\text { Chi-square Value }\end{array}$ & P-value & Conclusion \\
Age & 68.529 & 0.856 & not significant \\
Gender & 0.754 & 0.686 & not significant \\
Civil status & 3.629 & 0.727 & not significant \\
Educational attainment & 12.809 & 0.542 & not significant \\
Religion & 8.678 & 0.193 & not significant \\
Number of years living in & 97.099 & 0.393 & not significant \\
respective barangay & & 0.256 & not significant \\
Family size & 25.904 & 0.958 & not significant \\
Annual family income & 32.471 & 0.295 & not significant \\
\hline
\end{tabular}

*Significant at $5 \%$. 
Table 12. Summary of Pearson Chi-Square Value between respondent' socio-demographic characteristic and nature of participation in the ecotourism project.

\begin{tabular}{cccc}
\hline Variables & $\begin{array}{c}\text { Pearson } \\
\text { Chi-square Value }\end{array}$ & P-value & Conclusion \\
Age & 124.840 & 0.437 & not significant \\
Gender & 9.946 & $0.019^{*}$ & significant \\
Civil status & 17.123 & $0.047^{*}$ & significant \\
Educational attainment & 14.442 & 0.850 & not significant \\
Religion & 17.629 & $0.040^{*}$ & significant \\
Number of years living in \\
respective barangay
\end{tabular}

*Significant at $5 \%$.

Based on the results, the males, as compared to females are more likely to see themselves as someone who can help in the tourism project and thus they tend to participate more or be more involved in the project's different activities and operations. It is also more likely that they view themselves as helpful sources of information regarding the project than the females.

Furthermore, males have the greater tendency to act less of a leader and a supervisor but more of a follower who usually does what the project proponents tell them to do and follow or act on the decisions made upon them. They also tend to assume more particular roles in the project and they assume to be one the project's beneficiaries.

Respondents who were married, those who were of Roman Catholic religion, those who belong to the working-class income group, and those who are members of certain organizations exhibit the similar nature of participation to the project.

This findings are in accordance with Mensah's (2016) [33] observation that gender is significantly related to community participation, with men participating more than women. Mensah also noted that there is significant relationship between nature of participation and income as well as perceived economic benefits of tourism.

\subsubsection{Socio-Demographic Characteristics and Level of Participation}

Chi-square results showed that there was no relationship between the respondents' age, gender, civil status, educational attainment, religion, number of years living in the barangay, family size, and annual family income with their level of 
participation at $5 \%$ level of significance. There is evidence to say so since the equivalent p-vales are greater than 0.05 alpha. This contradicts Mubanga and Umar's (2016) [14] observation that level of participation in tourism activities is associated with respondents' income levels, particularly, there is low participation among low-income households.

This study found that being a member of organization is the only socio demographic characteristic that is related to the respondent's level of participation, since its p-value is less than the 0.05 level of significance (Table 13).

This implies that people who are members of certain organizations are more likely to have higher participation in the project than those who are non-members. They tend to be more involved in the project's various activities and operations. It can be said that organizations play an important role in enabling the people to be more concerned about the project and make them participate more in it.

\subsubsection{Perceived Role and Level of Awareness}

Chi-square results showed that there was no relationship between the respondents' perceived role and their level of awareness of the ecotourism project since the equivalent p-values are greater than 0.05 alpha (Table 14).

\subsubsection{Level of Participation and Level of Awareness}

Chi-square results showed that there was no relationship between the respondents' level of participation and their level of awareness of the ecotourism project. There is evidence to say so since the 0.069 is greater than 0.05 alpha (Table 15).

Table 13. Summary of Pearson Chi-Square Value between respondents' socio-demographic characteristic and the level of participation in the ecotourism project.

\begin{tabular}{cccc}
\hline Variables & $\begin{array}{c}\text { Pearson } \\
\text { Chi-square Value }\end{array}$ & P-value & Conclusion \\
Age & 160.512 & 0.562 & not significant \\
Gender & 8.631 & 0.071 & not significant \\
Civil status & 15.216 & 0.230 & not significant \\
Educational attainment & 20.483 & 0.846 & not significant \\
Religion & 8.472 & 0.747 & not significant \\
Number of years living in & 182.641 & 0.597 & not significant \\
respective barangay & 51.862 & 0.194 & not significant \\
Family size & 111.365 & 0.135 & not significant \\
Annual family income & 28.482 & $0.000^{*}$ & significant \\
\hline
\end{tabular}

${ }^{\star}$ Significant at $5 \%$. 
Table 14. Summary of Pearson Chi-Square Value between the respondents' perceived role and level of awareness of the ecotourism project.

\begin{tabular}{cccc}
\hline Variables & $\begin{array}{c}\text { Pearson } \\
\text { Chi-square Value }\end{array}$ & P-value & Conclusion \\
\hline $\begin{array}{c}\text { Staff member of this project } \\
\begin{array}{c}\text { Leader of an organization that is } \\
\text { involved in the project }\end{array}\end{array}$ & 0.940 & 0.625 & not significant \\
$\begin{array}{c}\text { Leader of an organization that is } \\
\text { not involved in the project }\end{array}$ & 2.587 & 0.680 & not significant \\
$\quad \begin{array}{l}\text { Involved citizen } \\
\text { Client or beneficiary of or recipient } \\
\text { of services from this project }\end{array}$ & 0.162 & 0.274 & not significant \\
$\begin{array}{c}\text { Local government or municipal } \\
\text { tourism officer }\end{array}$ & 2.353 & 0.112 & not significant \\
$\begin{array}{c}\text { Length of service in years assuming } \\
\text { that role }\end{array}$ & 36.168 & 0.554 & not significant \\
\hline
\end{tabular}

Table 15. Summary of Pearson Chi-Square Value between the respondents' level of participation and level of awareness of the ecotourism project.

\begin{tabular}{ccc}
\hline Pearson chi-square value & P-value & Conclusion \\
\hline 14.535 & 0.069 & not significant \\
\hline
\end{tabular}

\section{Conclusion}

Since the data used in the study were gathered from randomly chosen respondents, the following can be concluded for the whole population of household heads of Paniman, Caramoan, Camarines Sur:

1) Majority of the people were $34-41$ years old males who were already married and whose families were composed of 5 - 6 members. Most of them were high school graduates. As for their religion, almost all of them were Roman Catholics. They were born in their barangay and had lived there for almost the entirety of their lives. They belonged to the low-income group in the Philippines. Some of them were affiliated with at least one organization.

2) The people's level of awareness of the ecotourism project was relatively high. All knew about the existence of the project. The ones who were very aware are those who are directly involved in the project as staff member and members of organizations working for the benefit of the project.

3) Public announcements and interpersonal sources were the two most popular ways of knowing about the project. Based on this, it can be implied that the residents of Paniman in Caramoan, Camarines Sur rely heavily on the local government and other residents to relay messages to them.

4) The project proponents seemed to limit the involvement of the people to 
assisting visitors and tourist, and attending orientations, trainings and seminars only.

5) People perceived their role in the ecotourism project as concerned citizens only. They participated in the project only when they want to or if they feel that they are needed at some point in time. However, some of them were members of organizations directly involved in the project and some are staff members of it.

6) The nature of participation of the people could be described as mere followers of the leaders and supervisors of the project. People took the orders and decisions from those who lead and those who supervise them. They involved themselves in the project because they believed that they could be of help to the project and can benefit from it.

7) It was evident that the description of participation of the respondents based on their agreed statements fitted the description of Pretty's first three levels of participation. Thus, the extent of community participation of Barangay Paniman falls under the third level of participation which is participated by consultation. Based on this, it could be implied that the level of community participation in the area was low.

8) Membership in organization was the only variable found to be positively related to the level of participation in the ecotourism project. People belonging to organizations tend to be more involved in the project than those people who are non-members of organizations. On the other hand, gender, civil status, religion, annual family income and being a member of an organization were found to be significantly related to the nature of people's participation. These certain socio-demographic characteristics have significant effects on the way the respondents participate in the project.

\section{Recommendations}

For the Barangay Tourism Office of Paniman, Caramoan, Camarines Sur:

1) The Barangay Tourism Office must try to establish a much higher level of participation from its residents to address project sustainability. Residents should have a say on whatever is happening with the project since it is their own resources that the project is utilizing.

2) Public announcements, communication by word of mouth, attendance of residents in meetings, trainings, and seminars regarding the project must be monitored and enhanced to make sure that more residents understand the purpose of the project and why the tourism office need their participation or involvement.

3) Similar studies on community participation can focus on finding out what motivates the residents to participate in ecotourism-related projects or knowing the effects of community participation on the project and the people itself using the qualitative approach.

\section{Acknowledgement}

The researcher would like to thank Partido State University for funding the re- 
search and the constituents of Brgy, Paniman, Caramoan, Camarines for their participation.

\section{Conflicts of Interest}

The author declares no conflicts of interest.

\section{References}

[1] Moica, C., Florece, L., Ancog, R. and Sereno, R. (2019) Waste Management System and Its Effects on the Water Quality of an Ecotourism Destination in Caramoan, Camarines Sur, Philippines. The 16th International Conference on Environmental Science and Technology Rhodes, Rhodes, 4-7 September 2019.

[2] Mefalopulos, P. (2008) Development Communication Sourcebook: Broadening the Boundaries of Communication. The World Bank, Washington DC. https://doi.org/10.1596/978-0-8213-7522-8

[3] Sirakaya, E., Sasidharan, V. and Sönmez, S. (1999) Redefining Ecotourism: The Need for a Supply Side View. Journal of Travel Research, 38, 168-172. https://doi.org/10.1177/004728759903800210

[4] Garrod, B. (2003) Local Participation in the Planning and Management of Ecotourism: A Revised Model Approach. Journal of Ecotourism, 2, 33-53. https://doi.org/10.1080/14724040308668132

[5] Carballo-Sandoval (1999) Community Involvement in Sustainable Ecotourism: The Case of the Mexican Caribbean Area. Geographical Paper No. 140, The University of Reading, Reading.

[6] Rebuya, N. (2020) Resource Protection Strategies towards Sustainable Ecotourism and Protected Area Conservation: A Visitors' Evaluation in Bulusan Volcano Natural Park, Philippines. International Journal of Tourism and Hospitality Reviews, 7, 12-19. https://doi.org/10.18510/ijthr.2020.722

[7] Setokoe, T.J., Ramukumba, T. and Ferreira, I.W. (2019) Community Participation in the Development of Rural Areas: A Leaders' Perspective of Tourism. African Journal of Hospitality, Tourism and Leisure, 8, 1-15.

[8] Reid, J.N. (2000) Community Participation: How People Power Brings Sustainable Benefits to Communities. USDA Office of Community Development.

[9] Richardson, A. (1983) Participation: Concepts in Social Policy. T.J. Press Ltd., Padstow.

[10] Stoker, G. (1997) Local Political Participation. In: Hambleton, R., et al., Eds., New Perspectives on Local Governance: Reviewing the Research Evidence, Joseph Rowntree Foundation, York, 157-196.

[11] Cecchini, S. (2009) Cash Transfers and Participation. A Presentation on Human Rights and Cash Transfers Programmes in Geneva on February 26-27.

[12] Dzinavatonga, N. (2008) Community Participation and Project Sustainability in Rural Zimbabwe: The Case of Sangwe Communal Lands. University of Fort Hare, Alice.

[13] Sharma, M. (2007) Community Participation in Community-Based Rehabilitation Programmes. Asia Pacific Disability Rehabilitation Journal, 18, 151-157.

[14] Mubanga, K.H. and Umar, B.B. (2016) “Tourism Is for Foreigners”: Resident Views about Community Participation in Zambia's Tourist Capital. Tourism Culture and Communication, 16, 75-89. https://doi.org/10.3727/109830416X14655571061791

[15] Salleh, N.H.M., Shukor, M.S., Othman, R., Samsudin, M. and Idris, S.H.M. (2016) Factors of Local Community Participation in Tourism-Related Business: Case of 
Langkawi Island. International Journal of Social Science and Humanity, 6, 565-571. https://doi.org/10.7763/IJSSH.2016.V6.712

[16] Cheng, T.M., Wu, H.C., Wang, J.T.M. and Wu, M.R. (2019) Community Participation as a Mediating Factor on Residents' Attitudes towards Sustainable Tourism Development and Their Personal Environmentally Responsible Behaviour. Current Issues in Tourism, 22, 1764-1782. https://doi.org/10.1080/13683500.2017.1405383

[17] Kala, D. and Bagri, S.C. (2018) Barriers to Local Community Participation in Tourism Development: Evidence from Mountainous State Uttarakhand, India. Tourism: An International Interdisciplinary Journal, 66, 318-333.

[18] Mustapha, N.A. and Azman, I. (2013) Barriers to Community Participation in Tourism Development in Island Destination. Journal of Tourism, Hospitality and Culinary Arts (JTHCA), 5, 102-124.

[19] Towner, N. (2016) Community Participation and Emerging Surfing Tourism Destinations: A Case Study of the Mentawai Islands. Journal of Sport and Tourism, 20, 119. https://doi.org/10.1080/14775085.2016.1151819

[20] Chili, N.S. and Ngxongo, N.A. (2017) Challenges to Active Community Involvement in Tourism Development at Didima Resort-A Case Study of Umhlwazini Community in Bergville. African Journal of Hospitality, Tourism and Leisure, 6, 115.

[21] Bello, F.G., Lovelock, B. and Carr, N. (2017) Constraints of Community Participation in Protected Area-Based Tourism Planning: The Case of Malawi. Journal of Ecotourism, 16, 131-151. https://doi.org/10.1080/14724049.2016.1251444

[22] Wondirad, A. and Ewnetu, B. (2019) Community Participation in Tourism Development as a Tool to Foster Sustainable Land and Resource Use Practices in a National Park Milieu. Land Use Policy, 88, Article ID: 104155.

https://doi.org/10.1016/j.landusepol.2019.104155

[23] Saufi, A., O’Brien, D. and Wilkins, H. (2014) Inhibitors to Host Community Participation in Sustainable Tourism Development in Developing Countries. Journal of Sustainable Tourism, 22, 801-820. https://doi.org/10.1080/09669582.2013.861468

[24] Bello, F.G., Lovelock, B. and Carr, N. (2018) Enhancing Community Participation in Tourism Planning Associated with Protected Areas in Developing Countries: Lessons from Malawi. Tourism and Hospitality Research, 18, 309-320. https://doi.org/10.1177/1467358416647763

[25] Gutierrez, E.L.M. (2019) Participation in Tourism: Cases on Community-Based Tourism (CBT) in the Philippines. Ritsumeikan Journal of Asia Pacific Studies, 37, 23 36.

[26] Moyo, S. and Tichaawa, T.M. (2017) Community Involvement and Participation in Tourism Development: A Zimbabwe Study. African Journal of Hospitality, Tourism and Leisure, 6, 1-15.

[27] Mak, B.K., Cheung, L.T. and Hui, D.L. (2017) Community Participation in the Decision-Making Process for Sustainable Tourism Development in Rural Areas of Hong Kong, China. Sustainability, 9, 1695. https://doi.org/10.3390/su9101695

[28] Pretty, J.N. (1995) Regenerating Agriculture: Policies and Practice for Sustainability and Self-Reliance. Earthscan, London.

[29] Obua, J., Banana, A.Y. and Turyahabwe, N. (1998) Attitudes of Local Communities towards Forest Management Practices in Uganda: The Case of Budongo Forest Reserve. The Commonwealth Forestry Review, 77, 113-118.

[30] Ricaforte, B.G.R. (2010) Media Content Analysis on Ecotourism in Leading Philip- 
pine Broadsheets.

[31] Thetsane, R.M. (2019) Local Community Participation in Tourism Development: The Case of Katse Villages in Lesotho. Athens Journal of Tourism, 6, 123-140.

https://doi.org/10.30958/ajt.6-2-4

[32] Lekaota, L. (2015) The Importance of Rural Communities' Participation in the Management of Tourism Management: A Case Study from Lesotho. Worldwide Hospitality and Tourism Themes, 7, 453-462.

https://doi.org/10.1108/WHATT-06-2015-0029

[33] Mensah, I. (2016) Effects of Socio-Demographic Characteristics and Perceived Benefits of Tourism on Community Participation in Tourism in the Mesomagor Area of the Kakum National Park, Ghana. Athens Journal of Tourism, 3, 211-230.

https://doi.org/10.30958/ajt.3-3-3 